\title{
The disillusionment of Robert Dell: the intellectual journey of a Catholic socialist
}

Article

Accepted Version

Renshaw, D. (2019) The disillusionment of Robert Dell: the intellectual journey of a Catholic socialist. Intellectual History Review, 29 (2). pp. 337-358. ISSN 1749-6985 doi:

https://doi.org/10.1080/17496977.2017.1370898 Available at https://centaur.reading.ac.uk/74079/

It is advisable to refer to the publisher's version if you intend to cite from the work. See Guidance on citing.

To link to this article DOI: http://dx.doi.org/10.1080/17496977.2017.1370898

Publisher: Informa UK Limited

All outputs in CentAUR are protected by Intellectual Property Rights law, including copyright law. Copyright and IPR is retained by the creators or other copyright holders. Terms and conditions for use of this material are defined in the End User Agreement.

\section{www.reading.ac.uk/centaur}

\section{CentAUR}

Central Archive at the University of Reading

Reading's research outputs online 


\section{The disillusionment of Robert Dell: the intellectual journey of a Catholic socialist}

\section{Introduction}

The late-Victorian era was characterised by sustained social and political ferment, an extended period of time when the old certainties and old values that had informed and shaped intellectual discourse in Europe since the beginnings of the nineteenth century were dramatically called into question. In Britain in the 1890s a complacent sense of selfcongratulation and imperial pride was tempered by a deep anxiety about the future: racial, social, religious and political, soon to be heightened by a bloody and protracted colonial war in South Africa, a conflict that led to a renewed focus on the levels of poverty and malnutrition apparent in urban areas of Britain. ${ }^{1}$ New forces on both the left and right were emerging to challenge the hegemony of liberal capitalism. For many men and women who had been raised in the comfortable, if stifling, and apparently unchangeable world of midcentury Victorian middle class society, the experience of both discarding the old ways of conducting politics and worship, and adopting new radical forms of expression, were simultaneously disorientating and exhilarating. Radical left-wing thought in the latenineteenth century was extraordinarily fluid: everything, ideologically-speaking, was up for debate. $^{2}$

This article will examine how personal identity, political belief and ecclesiastical inclination were shaped by these new currents. It will attempt to do so by focusing on the political and spiritual journey of one man, the journalist and art critic Robert Dell 18651940), between 1890 and 1914. Dell is largely forgotten today, if he is remembered at all it is for his later career as a correspondent for the Manchester Guardian after the First World War and as a prescient early opponent of fascism. Dell's journey will be mapped out through reports of radical meetings, pamphlets, articles and private correspondence. In doing so the 
article will question what it meant to be a socialist in London in the last decade of the nineteenth century and the first decade of the twentieth, and the contested possibilities of combining socialism with religious faith. In Dell's case this was an attempt to reconcile a deep spiritual commitment to Catholicism with an equally passionate belief in social democracy. Dell did not merely desire his faith and his politics to be compatible, to sit comfortably with each other, but for the two to be bound together, reliant upon each other and drawing from the same political and spiritual well. In late-nineteenth century Britain both socialism and Catholicism provided new conduits for shaping self-definition and opportunities for satisfying that deep human desire - the need to reconcile one's personal existence with a greater (impersonal or supra-personal) cause. What distinguished Robert Dell was that he adopted both at very much the same time, and then attempted to ideologically reconcile the two. This article will examine the two key elements of this campaign Dell waged in print and at meetings over the course of a decade. Firstly, the article will examine the creation of a dichotomy conflating Catholicism with 'collectivism' (and thus socialism) and Protestantism with 'individualism' (capitalism). Secondly, the article will analyse distinctions within the nascent left between a moderate 'English' form of socialism and violent 'foreign' counterparts. More widely, the article will consider the possibilities of reconciling left-wing politics and religious faith, and the difficulties inherent in attempting to adhere to multiple, sometimes mutually contradictory, theoretical tenets. In the end these contradictory impulses, and especially the ruthlessness of the Church in dealing with perceived internal threats, could not be reconciled. Through focusing on Dell's own experiences and writing, and the now largely forgotten role that he played in a crucial formative period for both metropolitan socialism and English Catholicism, this article adopts a micro-historical perspective, but one that illuminates important and long-term macrohistorical trends in British politics and religion. 
In recent years an increasing amount of attention has begun to be paid to the interaction between socialism and faith in a British context in the late-nineteenth century, but the literature is still primarily focused on socialism and Protestantism, socialist roots in NonConformism, or the Labour Church that grew out of this relationship. ${ }^{3}$ The literature on the relationship between the Catholic Church and socialist movements in a specifically British nineteenth and early twentieth century framework is still extremely limited, the most detailed examination of the subject being Sheridan Gilley's 'Catholics and Socialists in Scotland, 1900-30' in the collection The Irish in Britain (1989). ${ }^{4}$ Gilley's essay in particular focuses on the relationship between the working class Irish Catholic diaspora and socialism as it manifested itself in urban Scotland. This article, however, will focus on London, and largely middle class interactions. Nevertheless, Gilley outlines some key points that will be addressed in this article, including the tensions within a Church that rejected socialism yet had deep reservations over unrestricted capitalism, and the question of whether religion, for the socialist, was a public or private affair. Of somewhat greater volume is the recent work on English Catholic Modernism, largely neglected until Vatican II reignited interest in past currents of progressive Catholicism. ${ }^{5}$ This article will draw on this literature, but within the context of the evolving belief-system of one individual, politically active at a crucial juncture in the history of British radicalism.

\section{(I) Catholicism and Socialism in Nineteenth Century Britain and Europe}

A matter of months after Karl Marx had committed to paper that challenge to the authority of 'all the powers of Old Europe... Pope and Czar, Metternich and Guizot, French Radicals and German police-spies..., ${ }^{6}$ Pope Pius IX, secure in his temporal power within the confines of the Vatican, formulated his own response to the unsettling events of the last year. Despite the continent-wide revolutionary activity of 1848 that so concerned the Pope being 
nationalistic rather than socialistic in character, Pius IX was in no doubt which groups presented the most significant and dangerous challenge to the continued spiritual and material well-being of the faithful and the rightful place of the international Church. In the encyclical Nostis Et Nobiscum, published in December 1849, Pius spoke of '...the pernicious fictions of socialism and communism', that such subversives were 'preparing [the working class] for plundering, stealing and usurping first [the] Church, and then everyone's property. After this they will profane all law, human and divine, to destroy divine worship and to subvert the entire ordering of civil societies.' 7

For Pius IX, the pernicious doctrines of socialism were but the latest manifestation of a subversive current antipathetical towards Catholicism that had sought to displace and undermine the Church since 1789. These sentiments were substantially repeated by Pius IX's successor, Leo XIII, who in 1878 issued an encyclical, Quod Apostolici Muneris, attacking socialism for its threat both to private property and the family unit, writing of the revolutionaries that: ' $\ldots$ they assail the rights of property sanctioned by natural law; and by a scheme of horrible wickedness... they strive to seize and hold in common whatever has been acquired either by title of lawful inheritance, or by labour of brain and hands, or by thrift in one's mode of life. ${ }^{8}$

Throughout the nineteenth century the Vatican displayed an unwavering hostility to all forms of political radicalism. Into the early twentieth century the Catholic hierarchy in Rome viewed socialism, another belief system with a supra-national structure (in the form of the Second International) and transnational reach and ambition, as a threat and a competitor. In Catholic continental Europe an apocalyptic confrontation between the Church and the revolutionary movement was widely predicted. Hilaire Belloc, the English Catholic intellectual, wrote that: 
... [The] nearer the Socialist theory comes to its moment of experiment... the more definite and the more uncompromising does Catholic opposition to it become... The movement of Socialism as it advances, discovers no other serious opponent beside the Catholic Church; and in a general survey of Europe I cannot but believe that the struggle between these two forces is the matter of our immediate future... the Socialist comes across the Catholic Church and for the first time meets a barrier... ${ }^{9}$

In the English context, with both Catholicism and revolutionary socialism at the turn of the century being very much minority concerns, the confrontation between the two was somewhat less pressing, but hierarchical attitudes towards socialism, and especially possible Catholic involvement in socialist organisations, remained hostile. One pamphlet from 1890 declared that ' $\ldots$ it becomes impossible for a well-instructed Catholic to advocate and encourage Socialism without contradicting the teaching of the Church. ${ }^{10}$ Cardinal Hebert Vaughan, Archbishop of Westminster from 1892 to 1903 and the conservatively-inclined successor to the more progressive Cardinal Manning, warned of the dangers of metropolitan Catholic youth, 'during the critical period between the ages of 14 and 21 ' being tempted by the 'deadly errors' of the 'Gospel of Socialism', 'the active organisations of unbelief and disorder.' $^{11}$

If the Catholic power structure viewed socialism, domestically and internationally, as a serious opponent, this feeling was reciprocated by much of the metropolitan socialist movement. Catholicism's supposed influence both in the corridors of power and, through mass Irish Catholic migration to London, Liverpool and other urban areas from the 1840s onwards, working class communities, fed the suspicions of those elements of the fin-de-siècle left already inclined to conspiracy theories. In particular, transnational clerical organisations such as the Society of Jesus (the Jesuits) were the targets of accusations of reactionary 
intrigue. In an 1893 article in Justice, the official organ of the Marxist group the Social Democratic Federation (SDF), entitled 'Socialists and the Roman Catholic Church' the correspondent concluded:

Where the Roman Catholic Church is mistress of the situation she is as tyrannous to-day as ever she was... Let us then, as Socialists, recognise, once and for all, the Roman Catholic Church is our most formidable opponent in every part of the world, and make ready to encounter the wiles of monks and priests with the organised force of an intelligent democracy. ${ }^{12}$

For sections of the British socialist movement, the Catholic Church, international and domestic, was a formidable and subtle enemy.

Nevertheless, despite this antipathy, there were attempts to synthesise or combine Catholicism and socialism. If the Catholic leadership were resolutely anti-socialist in political inclination, there was also a strong strain of anti-capitalism involved in Catholicism, and sympathy for the poorest sections of society, particularly in Britain during the long tenure of Cardinal Manning as Archbishop of Westminster. ${ }^{13}$ There was also a certain social awareness and social consciousness, an appreciation of the plight of the industrial working class, sometimes articulated by the Vatican, most notably in the 1891 encyclical Rerum Novarum. This communication acknowledged the dire conditions of manual labour in Europe since the industrial revolution and the iniquities of modern capitalist economy: '... the hiring of labour and the conduct of trade are concentrated into the hands of comparatively few; so that a small number of very rich men have been able to lay upon the teeming masses of the labouring poor a yoke little better than that of slavery itself. ${ }^{14}$ Nevertheless, the encyclical absolutely rejects socialism of any kind as a solution to the faults of capitalism, instead suggesting a solution rooted in the increase of charitable donations on the part of the rich and of the state, 
re-affirming ideas of 'holy poverty', and in respect to strike action arguing for the intervention of a benevolent state before serious conflict between worker and employer could ensue. $^{15}$

This being acknowledged, along with the collectivist as opposed to individualist narrative of the development of the Church, the Rerum Novarum pointed to the existence of political space where Catholicism and working class politics could be brought together. There were also currents at work in British Catholicism in the Edwardian period that, if not explicitly socialist in organisation or theory, aimed to modernise and liberalise certain aspects of the faith. This article will document the progress and ultimate failure of Catholic Modernism in Britain, and the effects that this failure had on attempts at a Catholic/socialist synthesis.

\section{(II) The Early Career of Robert Dell}

Robert Edward Dell was born into an upper-middle class Anglican family in 1865. His father was a Church of England clergyman, and Dell's grandfather had been a successful brewer in Wallingford, and a Conservative Member of Parliament, the picture of midVictorian bourgeoisie respectability. Dell went up to University College, Oxford in 1884, before moving to London in the late 1880 s to pursue a career in journalism and art

criticism. ${ }^{16}$ It was in this capacity as a journalist that Dell, in his mid-twenties, first began to display an interest in the radical political activity that was beginning to blossom in the capital, after a long fallow period. The socialist movement in London at this time was fragmented to an exceptional degree. The metropolitan left, ranging from the gradualist Marxist SDF to the anarcho-socialist Socialist League and the cerebral Fabian Society, as well as a series of smaller and more transient groups, was notoriously fratricidal and inclined to schism and 
discord, with overlapping and often-changing memberships. ${ }^{17}$ How socialism would take power, through permeation and infiltration of existing organisations and institutions, engagement with democratic politics and the ballot box, or through violent revolution, was not the least important question being debated at this time. This dichotomy of 'gradualist' and 'utopian' forms of socialist activity would be a crucial factor in Dell's attempts to reconcile his faith and his politics.

It was at the meetings of the Fabian Society that Robert Dell first began to attract attention from his contemporaries in the local socialist milieu. Dell, who had joined the Fabian Society in 1889, particularly involved himself in the radicalisation of railway workers in the capital. At a meeting held in Lambeth in March 1890, it was reported that: 'Dell said he was one of those wicked people who went about setting class against class, and he was afraid it was more or less necessary to do so at present, as unfortunately the interests of the capitalist class and the working class were diametrically opposed.' Dell, already contributing to a number of Fabian publications, went onto to discuss the role of the trade unions in the achievement of socialism. A Fabian report on the meeting read:

Not that he [Dell] believed that for a moment that trade unions would be able to effect the complete emancipation of the workers; that could only be effected by the destruction of private monopoly in land and capital. Nevertheless, the unions could play a useful part in creating class consciousness among the proletariat. To applause, Dell concluded that 'the sympathy of the middle classes could not be reckoned upon when where the action of any union, however righteous, interfered with their comfort and convenience... the workers must chiefly depend upon themselves if they wished to be successful. ${ }^{18}$ 
Two weeks later, at a meeting of railwaymen at Victoria Theatre in Newshaven, Dell expressed the same beliefs in much the same language. '... they [the workers] must aim ultimately at removing the great cause of all the evils they had to suffer - namely, the monopoly by the few means of production, so that those who worked might enjoy the wealth they produced.' ${ }^{19}$ If the sentiments Dell was expressing were not remarkable for the discourse of the time, his sincerity impressed his audience and fellow-speakers, Dell being described at one meeting as 'slight, quiet and self-possessed.' A French comrade whispered to a neighbour at one Fabian address that 'He'll [Dell] go far.' The English socialist sitting next to him replied 'I think so too. ${ }^{, 20}$ At a meeting in Hammersmith on April $3^{\text {rd }} 1890$ Dell shared a platform with Eleanor Marx, the daughter of Karl, who had been a key figure in the gasworkers' strike of the previous year, on the success of efforts to unionise shop assistants in the capital. Within days of this he would take part in a meeting with an even more impressive roster of speakers; at an open-air rally in Hyde Park on 11 May 1890 that Dell helped to organise, the crowd was addressed by George Bernard Shaw, Will Thorne, Annie Besant and Tom Mann among others. ${ }^{21}$ Over the course of the winter of 1890 and into 1891 Dell continued to address socialist meetings across the capital, from Kensington to Bethnal Green, including events organised by the Fabians, the Socialist League and the SDF, and with topics as varied as 'the Conditions of True Freedom' to 'Women and Socialism', and, with Sidney Webb, 'Methods of Social Evolution.' But increasingly, Dell's speeches and lectures concerned themselves with the confluence of socialism and religious faith, and in particular the Catholicism that Dell, although not yet a convert, was already attracted to. In 1892, the year that Dell was married, in St. Anne's, Lambeth, with the service presided over by the Christian socialist the Rev. W.C Morris, he also led the Fabian deputation to the funeral of Cardinal Manning, a deputation that had been formed at Dell's request. ${ }^{22}$ By the end of the 
year he was becoming increasingly identified in socialist circles with a particular form of radical Catholicism, although he did not officially convert until 1897.

\section{(III) The Appeal of Catholicism in Victorian and Edwardian Britain}

Dell's conversion to Catholicism was by no means exceptional for a young man from the upper-middle classes who had been brought up as an Anglian, born and raised in the heart of the Church of England. Over the second half of the nineteenth century Catholicism in Britain exercised a significant attraction to men and women from 'respectable' Protestant backgrounds, with a substantial number of high-profile conversions. One London-based Catholic priest, questioned by the social investigator Charles Booth on the heightened appeal of the Church, suggested some factors behind the movement:

The trend towards Catholicism is the outcome of a reaction against Evangelicism [sic] ... The Roman Catholic Church attracts English people through the senses much more than through the reason. They are attracted by the form of worship presented, and all the Churches are following the example of Rome... At present we do not increase in numbers in England, but we increase in position. The poor fall away, but the middle class is coming in; thus we gain in social condition, though in numbers we stand still... ${ }^{23}$

The Catholic Church offered both an appealing exoticism, with its ritual, its sacrament and masses conducted in Latin, but also a reassuring surety of world-view and hierarchical discipline, something absent from the Church of England in the second half of the nineteenth century. When Robert Dell was still a child, Victorian society was undergoing a severe and long-lasting crisis of faith and trust in conventional religious bodies, the catalyst for which had been Charles Darwin's publication of the Origins of Species in 1859. This challenge to the tenets of mainstream religious faith produced a number of different responses. For some, 
such as E.B Bax, the emergence of evolutionary theories led to a wholescale rejection of Christianity and the adoption of atheistic socialism. Others turned away from orthodox forms of religion and embraced spiritualism and a belief in the existence of various transcendental 'psychic phenomena'. ${ }^{24} \mathrm{~A}$ third response, however, rather than rejecting religious faith or embracing counter-cultural mysticism, was to seek out conventional ecclesiastical avenues that offered certainty and a sense of belonging that Anglicanism did not, and for many the Catholic Church provided this assurance. A significant number of the most influential Catholics in late-Victorian and Edwardian Britain were in fact converts from the Church of England, including Cardinal Manning and the Catholic Modernist Fr George Tyrrell. In the midst of his final break with the Church in 1906, Dell stressed that he had made a conscious decision to follow the Roman Church, describing himself as 'a Catholic not by inheritance or early training or habit but by deliberate choice. ${ }^{25}$ That Dell was a convert, rather than being born into the faith, increased both the fervency of his Catholicism in the 1890s, and the bitterness of the divorce a decade later.

Catholicism, like socialism, was thus expanding and on the ascent precisely at the point at which Dell first became involved in metropolitan politics. The Roman Church, like the Socialist International, was proving attractive to men and women responding to the breakdown in traditional belief and affiliation documented at the beginning of this article. The next section of the article will consider Dell's attempts to marry the two together.

\section{(IV) The Confluence of Socialism and Catholicism}

From the mid-1890s onwards Dell began to lecture and publish articles and pamphlets in the socialist press arguing for the confluence of socialism and Catholicism, working to make socialism acceptable to religious Catholics and Roman Catholicism and the Papacy 
palatable to a metropolitan left who, as indicated above, viewed the Catholic Church as a reactionary organisation working to retard the political progress of the working class, and had noted the frequent strictures against socialism issued by the Vatican. Dell set about this task in two ways. Firstly, he stressed the collective quality of Roman Catholicism as opposed to the individualism of Protestantism. Essentially this was a re-interpretation of the 'Merrie England' narrative of William Morris and Robert Blatchford, but with more emphasis laid on the role of the Catholic Church in pre-Reformation England as defender of the peasantry and the small yeoman farmer, and an explicit association of Protestantism and capitalism. ${ }^{26}$ Secondly, Dell re-interpreted, or attempted to re-interpret, the Papal condemnations of socialism and their relevance to the peculiar conditions of late-Victorian Britain. As shall be discussed, the attempts by Dell to present the Pope's words on the socialist movement in the most benign light possible draw criticism both from Dell's fellow socialists, and from antisocialist Catholics.

Dell, who loved France (indeed one of the fixed points in Dell's life was a passion for all things Gallic) and spent a great deal of time on the other side of the English Channel, must have been at least partially influenced in his conflation of Catholicism and politicised social justice by the Sillon movement led by Marc Sangnier that was taking root in Paris and spreading to the rest of France at the same as Dell was beginning his political engagement with both the Catholic Church and the Fabian Society. The Sillon organisation, formed in 1894, would prove highly influential both in Europe and the United States of America. Sillon, although it would attract significantly more popular grassroots support than Modernism would in Britain, in many respects followed the same trajectory as the British movement, a confluence of spiritual and material concerns, an expansion that led to conflict with the Church hierarchy, and finally, as we shall see, condemnation and suppression by the Vatican. ${ }^{27}$ The influence of Sangnier is apparent in much of Dell's literature produced up to 
1906. Nevertheless, it must be stressed that Dell was not a Modernist on the Sillon model, rather he was a Catholic socialist sympathetic to the efforts of Modernism in both France and Britain, and the distinction at this point must be drawn; neither Sangnier nor Fr. George Tyrrell would have identified themselves as socialists in any sense of the word. Although there was a definite confluence in spiritual and temporal concerns between these men and Dell, Dell's explicit socialism distinguished him from both.

In his 1899 monograph The Catholic Church and the Social Question, first published in the Catholic Herald as a series of articles, Dell set out the essentials of his arguments on Catholicism and society. In regards to the pre-Reformation 'golden age', under the benevolent authority of an indivisible Church, Dell depicted late-medieval Britain almost as a proto-socialist state:

In the middle ages, when the teaching of the Church was supreme, there was no competition as we understand it now, no freedom on contact [sic] in our modern sense, industry was duly organised and regulated, and it was universally recognised that the rights of property are not absolute... [A]griculture was carried on what were practically co-operative lines, and the whole idea of society as that of an ordered 'commonweal' in which, as in the Church, the individuals composing it were viewed as members one of another, with their own appointed functions, working together for the common good, not against each other for their own individual advantage. ${ }^{28}$

Dell recognised that this idyllic scenario was impractical at the turn of the twentieth century. Having outlined the arcadia of the late middle ages, Dell concluded that '.. the fact we have to face is the complete change in the system of production, brought about by the invention of machinery and the ensuing sub-division of labour, which makes a return to the 'small 
industry' as regards the bulk of commodities, quite impossible. ${ }^{29} \mathrm{He}$ continued, with more than a hint of anti-Semitism, that:

... [It] would be, for many reasons, desirable to set up a system of small farmers, owning their own land. But here again we are met with a like difficulty... for in fact it has been found that, where a system of small proprietorship has prevailed, the land has become the property of Jewish usurers. ${ }^{30}$

Nevertheless, despite having recognised the practical limitations of resurrecting this preReformation, pre-industrial social and economic structure, the message was clear - social equality and just economic redistribution were not only compatible with Catholicism, but that under the control of the medieval Church and its institutions England had come closer to achieving practical socialism than at any point subsequently. The history of the Church, presented in this light, suggested its potential as a progressive and socially-aware body that involved itself in the lives and struggles of its congregations, rather than the reactionary, authoritarian and aloof organisation it was frequently depicted as in socialist discourse. '[The Church] alone of all religious bodies, has a system of moral theology, and holds up moral standards and social principles which have stood the test of nineteen centuries and can be applied to any stage of evolution. ${ }^{31}$ Other contemporary socialists writing at around the same time echoed these sentiments and this interpretation of English social history. T.D Benson writing three years later in a pamphlet entitled $A$ Socialist's View of the Reformation, stressed the progressive attitudes of the medieval Church towards the poor. 'Not only was the Church instrumental by the inculcation and practice of charity in assisting the distressed, but on her own estates which... extended to nearly half of the country, she had unlimited opportunities of giving work to the dispossessed labourers, or of letting them land for cultivation. ${ }^{32}$ On the effects of the Reformation on society, Benson wrote: 
... the inculcation of the Protestant virtue of thrift instead of the Christian virtue of charity... making the worker the helpless wage slave of the idle landlord and manufacturer... This is the tragedy of the Reformation... The commercial sprit overthrew authority in matters of opinion and faith... The [first effect] was not liberty but licence, giving rise to a multitude of sects, in which true religion perished and atheism arose amidst the clash of creeds... above all, license to a few to exploit, enslave and degrade the many. ${ }^{33}$

'Commercialism', wrote Dell, 'indeed is the twin sister of Protestantism, and it is as natural for a Protestant be an individualist in social matters as it is unnatural for a Catholic.' 34 In this manner, elements of the socialist movement combined two separate historical interpretations of the evolution of British society since the sixteenth century, ecclesiastical and economic. This narrative conflating Protestantism with capitalism ran counter to a parallel socialist discourse expressing sympathy for the smaller Protestant non-conformist groups, which much of the labour movement and many of the most effective socialist and trade union leaders of the time had emerged from. Into the twentieth century the 'low Church' and the Labour Church movement that grew out of it would have a profound influence on the development of the Labour Party. ${ }^{35}$ The non-conformist roots of British socialism also fed a residual suspicion of Catholicism. ${ }^{36}$

In The Catholic Church and the Social Question Dell also confronted head on the Papal condemnations of radical politics as morally and socially harmful that had periodically been issued since the mid-nineteenth century. In doing so he challenged those outside the socialist movement who viewed the gamut of political positons contained within the appellation 'socialism', from anarchists to social democrats, as one monolithic, cohesive block. Dell instead suggested a binary opposition between peaceful domestic progressive socialism rooted in constitutional methods and other elements that he suggested were the true targets of 
Papal hostility. Dell stressed this distinction between social democracy on the one hand and 'utopian' anarchism, nihilism and communism on the other. In a paragraph that encapsulated Dell's political position at this time, he posed the rhetorical question:

Can a good Catholic be a socialist?... Of course the answer depends on what is meant by a 'socialist'. The word 'socialism' is applied by different people to a great many theories, fundamentally different in character. Some of these... are incompatible with Catholic morality, while others, on the contrary, not only do not involve anything that is incompatible with a loyal submission to the teaching of the Church, but rather are pointed to by that teaching and seen to be the means whereby in our present industrial conditions it can be put into practice. ${ }^{37}$

Catholicism thus led the way to socialism, that is a moderate 'acceptable' and 'English' form of socialism, and provided the means by which socialism could be implemented. This echoes the sentiment of the High Anglican Guild of St Matthew:'Is the reader of this paper a Catholic? Then let him ask himself why he is not a socialist. Is he a socialist? Then what hinders him from declaring himself a Catholic?' ${ }^{38}$ Dell argued that 'catastrophic socialism', utopian revolutionary activity aiming for a complete re-ordering of society through a violent uprising, was 'rapidly dying out, and in England is almost extinct. ${ }^{39}$ Finally, Dell addressed the positon of the Vatican hierarchy on left-wing politics:

When Leo XIII speaks of the "pest of socialism" and "the deadly plant of socialism" he is referring to a socialism which teaches that private property is immoral... Collectivism has no such aim. And when the Holy Father speaks of socialists who "contend that neither honour nor respect is owed to public authority, nor any obedience to the laws" he is certainly not speaking of "socialism" as we understand it in England, which on the contrary aims at the 
increase of authority and greater power for government. The socialism which the Holy Father denounces consists in certain moral doctrines of revolutionary communists and anarchists... To apply the Holy Father's words to the entirely constitutional collectivism of the Fabian society or the Independent Labour Party' would be a [monstrous] distortion of language... ${ }^{40}$

At this time Dell championed a moderate strand of socialism drawing on a Catholic heritage and traditions and fusing the collectivism of Catholicism and socialism together, simultaneously downplaying both the strength of non-constitutional forms of political radicalism in England and the blanket condemnations of the Papacy.

However, certain Catholic writers from the early 1890s onwards had rejected precisely the argument Dell advanced in 1899. Kenelm Digby West rejected what he saw as the spurious distinctions between violent and non-violent forms of socialism.

Socialists also will vainly try to excuse and defend themselves by saying there are different kinds of Socialists, and that we are not asked to sympathise with Nihilists, Anarchists or even Social Democrats, but only the orderly, harmless, philanthropical [sic], speculative Socialists, whose theories and doctrines, they aver, clash neither with the teachings of the Church, nor with the revealed law of God. Indeed, they claim to find in the spirit of the Gospel and its words a justification for their innocent programme of universal benevolence. I say, it will not do - "it won't wash"41

Correspondence to the socialist press of the 1890 s testifies to the conflicting loyalties of Catholic socialists attempting to put into practice Dell's conflation of faith and politics. A 'Roman Catholic Socialist' writing to Blatchford's Clarion made clear the difficulties apparent in this hybrid identity: 
I am a Roman Catholic and a practical Socialist, though not a member of the SDF. I have amongst my fellow tradesmen done my share and have won a few votes for the cause of labour in a quiet way. Now if a Catholic cannot be true to his religion and at the same time be a socialist, I, for one, am going to sacrifice Socialism for my religion. If, on the other hand, a Catholic can be a Socialist, tell me why those alleged labour leaders invariably attack Catholic doctrines?... ${ }^{42}$

Another correspondent to the same journal revealed the tensions within the Catholic clergy over political positon:

I know many [priests] who are socialists, and I also know of many who have been 'silenced' because of their socialism... Then again, I was refused communion by the priest of the parish in which I was living at the time unless I gave up socialism... I was denounced from the altar because of my socialism. Why, again, this vindictiveness because of holding an honest opinion $?^{43}$

Thus, whilst in many respects Dell was merely agreeing with the concepts put forward by more prominent non-Catholic English socialists of the period, that late-nineteenth century Britain was a fundamentally less equal society than it had been before the Reformation, and that socialism's future lay in peaceful gradualism rather than violent revolutionary change, his factoring of the Catholic Church into the equation proved a barrier between Dell and his comrades. The majority of Dell's fellow-socialists assumed that the Catholic Church, like other official religious bodies, was basically conservative. As the correspondence quoted above confirms, they were usually correct in this assumption, excepting the divergent paths taken by a number of individuals. For Dell, this was soon to become apparent in the Modernist controversies from the end of the nineteenth century onwards. 


\section{(V) Disillusionment}

The Catholic Church and the Social Question was a bold statement of faith and intent by Dell; it also marked the highpoint of his belief that the 'official' Catholicism of the Vatican could be reconciled with a progressive left-wing agenda. After 1899, at first gradually, and then rapidly, disillusionment with the Papal hierarchy and what Dell perceived as a resilient reactionary agenda set in. Disillusionment soon turned to alienation, and alienation to hostility. The catalyst for Dell's dramatic ideological turn around was the reaction of the Church, both international and domestic, to the emergence of what became known as 'Catholic Modernism' and in particular the treatment of two prominent English Liberal Catholics, St George Mivart and Fr George Tyrrell. Modernism, which emerged in the final years of the nineteenth century, was essentially a call for the Church to adapt to and recognise the profound social and political changes that had taken place over the last half century, as Clyde F. Crews writes, '... an attempt at a response to the explosion of knowledge and criticism that confronted the believer as a result of nineteenth century intellectual and scientific developments', and also for the Church to take a more engaged role in society. ${ }^{44}$ Modernism, focusing on both spiritual and social matters, was not a call for socialism, but Dell certainly agreed with the sentiments being expressed by its proponents, and the response of the Catholic hierarchy to these attempts to forge a more engaged and socially-aware religious structure was for Dell a litmus test for the practicality of forging that progressive Catholicism he had been writing and lecturing on for almost a decade.

Dell's disillusionment and eventual break with the Church began with the treatment of St George Mivart by the domestic Roman Catholic leadership. Mivart, a convert to Catholicism in his youth, was a prominent biologist who from the mid-1870s onwards had campaigned for a more liberal and scientific approach to Catholic faith. Mivart's final departure from the 'official' Church was sparked by what Mivart perceived as both the 
complicity of the French clergy and the silence of the international hierarchy on the on-going legal persecution of Alfred Dreyfus, which had grown from a localised miscarriage of justice to a Europe-wide scandal. ${ }^{45}$ Mivart's condemnation of the role of the French and international Catholic Church in the Dreyfus Affair was coupled with a general criticism of the antiprogressive stance of the Church on a range of social issues. There followed an increasingly bitter exchange of letters between an infirm Mivart and Cardinal Vaughan. Vaughan wrote to Mivart that:

You have publically impugned the most sacred and fundamental doctrines of the Faith, while still professing yourself to be a Catholic. It becomes, therefore, my primary duty, as guardian of the Faith, to ascertain whether I am still to treat you as a member of the Church and subject to my jurisdiction or to consider you outside the unity of the Faith. ${ }^{46}$

When Mivart refused to renounce his errors, he was excommunicated, and died soon after. Mivart was refused Catholic burial, until a face-saving arrangement was arrived at with Mivart's family that the biologist had been 'of unsound mind' when he had broken with the Church. $^{47}$

The brutal treatment of Mivart, both in life and death, by the hierarchy was a blow for Dell. In April 1900, days after Mivart had died of a heart attack, Dell addressed the controversy in an article in The Nineteenth Century entitled 'A Liberal Catholic View of the Case of Dr Mivart'. That Dell was losing faith with the institutions of the Catholic establishment was clear. Having written that the Church, as a body, was 'relapsing', 'as far as intellectual vigour and mental capacity are concerned', and condemned the reaction of the English Catholic press to the Mivart affair, Dell continued: 
In the domain of philosophy there has taken place during the last half-century in the Catholic Church a thorough-going reaction, and an organised attempt has been and is being made to resuscitate a dead philosophical system and impose it on all Catholics. The result is that Catholic theologians and philosophers are wholly out of touch with modern thought. ${ }^{48}$

In this article Dell limits his attacks to sections of the hierarchy, in particular the theological schools that he viewed as bastions of reaction, rather than the 'official' Church as a body. At one point he defends the Jesuits against criticism from 'Protestant fanatics', and concludes the article on an optimistic note. '... [The] Roman Church has certain practical qualities, such as that of compromising when she sees she must, apart from theological considerations, [that] make her the natural Mother and Mistress of all the Churches. ${ }^{49}$ At this point Dell was still confident, at least publically, that the mainstream Church and progressive forces could be fused together, despite the treatment meted out to Mivart. In the conclusion to the article, Dell maintained that the Church was adaptable and still capable of reform. Nevertheless, the Mivart affair forced Dell to accept the strength and durability of conservative elements within the hierarchy, and the belief expressed the year before in the essential compatibility of a peaceful English socialism and Papal edicts was fading.

If the treatment of St George Mivart had shaken Dell's faith in 'official' Catholicism, the controversy over Fr George Tyrrell, a personal friend of Dell's, led to a final and irreconcilable break with the Church. By the time Dell relocated to France in 1905, his positon on the relationship of the Catholic Church and progressive politics had undergone a considerable evolution. This was in the context of a hardening of the attitude of the Catholic establishment towards attempts at liberalisation. Pius X, who had become Pope in August 1903 on the death of Leo XIII, identified Modernism as an enemy of international Catholicism. The Pope declared that the Vatican would 'take the utmost care to see that 
members of the clergy are not ensnared by the cunning of a certain new science which is endeavouring to pave the way for rationalism. ${ }^{50}$ Pius $\mathrm{X}$ demanded that the 'Modernists' should be 'beaten with fists. ${ }^{51}$ In England the prime target for this crackdown on liberal tendencies was George Tyrrell. Like Mivart, Tyrrell had argued for a more progressive interpretation of Catholicism for a number of years, but did not come into direct confrontation with the hierarchy until 1903-04. For Tyrrell, the Church had become overly regimented, had lost its spiritual way and forgotten its vocation to minister to the poorest and most vulnerable. In a 1903 monograph, published under the penname of Hilaire Bourdon, Tyrrell wrote that, '... the "official" Church of today has no other idea than that of protection, absolute and unqualified, as far as it can be possibly carried out... the Catholic body as a whole... is becoming steadily enfeebled and emasculated, both mentally and morally., ${ }^{, 52}$ Tyrrell compared the reactionary political position of the international Church and its sanctions against its opponents with those of the Russian Tsarist regime. ${ }^{53}$

Tyrrell was a Jesuit - now the Society of Jesus became the target for much of Tyrrell's opprobrium. When at the end of December 1900, a few months after the death of Mivart, the English Catholic bishops had issued a joint pastoral letter attacking liberal and Modernist theology, Tyrrell believed it in fact to have been drafted by the Jesuits in Rome, and that it was a personal attack on him and other Catholic Modernists. ${ }^{54}$ From this point Tyrrell and his close friend and fellow Modernist Maude Petre were the subject of a concerted campaign by the metropolitan Catholic leadership to pressure them into renouncing liberal tendencies, a campaign that only ended with Tyrrell's death in 1909. Tyrrell was excommunicated; Petre was threatened with the same and expelled from the London Council of the Daughters of the Heart of Mary. ${ }^{55}$ As with Mivart, Tyrrell's burial became a point of controversy. Tyrrell had received the sacrament, but was refused Catholic burial for having failed to recant his liberal views; a Catholic priest, the Abbe Henri Bremond, was 
excommunicated for speaking a eulogy over Tyrrell's grave at a Protestant graveyard in Storrington in Sussex. ${ }^{56}$ With Tyrrell's death English Catholic Modernism had effectively been defeated by the hierarchy. Petre remained a lone figure in the liberal wilderness, describing herself in 1922 as 'a solitary, marooned passenger; the sole living representative of what has come to be regarded as a lost cause - the cause of Modernism in the Roman Catholic Church. ${ }^{57}$

\section{(VI) The Break}

The destruction of Modernism, and the way in which the campaign against it and its proponents had been conducted, led to a dramatic transformation of Robert Dell's beliefs on the Church and socialism. From a writer who had for almost a decade stressed the progressive and collectivist aspects of 'official' Catholicism in its Vatican-approved form and the positive contributions the Church had made both historically and contemporaneously to human equality and progress, Dell became a bitter opponent of the Vatican and the Church hierarchy, both in England and France. In a number of pamphlets and articles issued in 1905 and 1906, Dell attacked the motives and actions of the Church leadership, and revised and reversed many of the assertions he had made in The Catholic Church and the Social Question. In an article in the Socialist Review from August 1906 Dell made explicit the new positon he had arrived at. He comprehensively demolished the arcadian vision of a return to a proto-socialist England under the control of a benevolent Catholic Church that he had posited seven years previously:

We do not propose to exchange the present system for a sort of revised medieval society with a 'living wage', peasant proprietorship, a graduated social hierarchy, an endowed and privileged Church and a paternal government duly submissive to 
the representatives of God on earth. This is the social problem which the Papacy proposes as the alternative to social democracy. ${ }^{58}$

What had been a positive aspect of pre-Reformation England seven years before, that is the central role of the Catholic Church in society, was now decidedly negative. Dell then addressed his own previous political position:

I once cherished the illusion that the Papacy and socialism could be reconciled... Facts and experience have blown my arguments to pieces... Socialism, as we understand it, involves not only the collective ownership of the means of production, but also equality, liberty and democracy. With none of these can the claims of the Papacy be reconciled. ${ }^{59}$

Earlier in the article Dell again exhibited that strain of anti-Semitic sentiment that was apparent in his earlier work on Catholicism and collectivism referred to in this article. On the Catholic press in France Dell wrote that 'Some of the leading clerical newspapers are directed by more or less converted Jews... Moreover, the financial affairs of the Vatican... are in the hands of the illustrious house of Rothschild. ${ }^{90}$ Dell concluded that:

Whatever may happen to the Papacy and the official Church, my faith in the future of Catholicism remains unshaken... There is no necessary opposition between Socialism and Catholicism as such; on the contrary they are both expressions of the social idea and the Catholicism of the future will resemble the Catholicism of the past more than the butterfly resembles the chrysalis. ${ }^{61}$

Tyrrell and Petre never renounced their Catholicism, or embraced another faith or none; at this point neither did Dell. ${ }^{62}$ Earlier in 1906, in an article in the Nineteenth Century, Dell had 
queried the attitude of the Church hierarchy towards religious toleration, and speculated what would happen if the Catholic Church ever re-established itself in Britain.

...[They] [the Church] are bound by the principles laid down in the encyclical 'Vehementer Nos' [an encyclical condemning contemporary legislation by the French government to separate church and state], and those principles condemn this system of toleration and equality absolutely and unequivocally... Would there be any compliments to a regime of toleration and equality if Catholics had never been reduced to an insignificant minority? Would there even be any toleration or religious equality if the Catholic Church had retained her hold on England ${ }^{63}$

In some significant respects Dell was now making use of the sectarian language and imagery of papal power employed by the 'Protestant fanatics of the ignorant and vulgar type' that he had condemned in the same journal six years previously. ${ }^{64}$ Dell repeated these sentiments in an article in the Saturday Review in October 1906. 'In a Protestant country the Roman See will acquiesce in religious toleration and accept equal rights with other bodies; in a Catholic country it will not.' 65

As the Church hierarchy effectively crushed the Modernist strain of socially-aware Catholicism in Britain, so the French Sillon movement also fell beneath the harrow of Vatican condemnation. For Dell, living in France, it must have felt as if progressive Catholicism was being systematically taken apart in both the country of his birth and his adopted home. Between 1907 and 1910 the Sillon in effect ceased to function as an organisation. Sangnier, unlike Dell or Tyrrell, accepted the criticism of the Church, at least in public, and resigned his leadership of the movement. ${ }^{66}$ In August 1910 Pope Pius X, in a letter to the senior French clergy, effectively gave the death notice for the French school of 
Modernism, when he wrote that the Sillon had exhibited a 'generous zeal in a direction as disastrous as it is dangerous' and had attempted to undermine the very principles at the heart of Catholicism. ${ }^{67}$ It is in this context, and that of an escalation of tensions between Church and State in France, that Dell's increasingly bitter reflections on the Catholic leadership were written.

This suspicion of the agendas of the Church hierarchy, and outrage at the treatment of Tyrrell, is reflected in the private correspondence of Dell to his family and colleagues back in England between 1907 and 1910. On Tyrrell's excommunication, Dell speculated in a letter to A. Lilley on possible responses to the Church's move, revealing a degree of cynicism on the motivations of his (former) co-religionists:

I agree with you entirely as to the desirability of a public protest, but whether it is possible to make an effective one is another matter. You know what miserable cowards most of our people [are]... If it is the salvation of their miserable souls they are thinking about, that makes the matter worse... if there are to be excommunications, the more the better; I have always thought that. ${ }^{68}$

At this time Dell was also attempting to set up a journal to promote the aims of Catholic Modernism, a plan that eventually came to nothing. A series of letters between Dell in Paris and his two daughters in England in the summer of 1910 point to a complete break with the tenets of Roman Catholicism:

There is such a thing as Eternal Justice and it triumphs on the whole and [in] the long run; that is the reason why the Catholics have come to grief in France and the Papacy is coming to grief all over the world. All causes that depend on force and persecution and slander and injustice come to grief in the end... ${ }^{69}$ 
In a later letter to his daughters, Dell concluded that: 'There is so little Christianity in Catholicism that, when Catholics give up their superstitions, there is hardly anything left.' 70

In effect, by 1906 Dell, who six years previously had argued so passionately for the compatibility of his politics and his religious faith, had now arrived at a positon very similar to that of Blatchford and Hyndman; that the official Catholic hierarchy was inherently reactionary, that Catholicism in its present state could only be a barrier to the achievement of socialism, not a conduit. An enthusiasm for the role of the 'Holy Father' in combating poverty and inequality had been replaced by a suspicion of insidious Catholic 'influence' not out of place in contemporary sectarian anti-Catholic literature.

\section{After Catholicism}

The 'Catholic period' of Robert Dell's life was over. In his 1940 obituary in the Manchester Guardian, for whom Dell became Paris correspondent in 1912, the paper commented, referring to his artistic tastes, that 'these interests, strong as they were when they were alive, seemed as if they had never been when replaced with others. ${ }^{71}$ These sentiments could equally be applied to Dell's relationship with Catholicism. No-one doubted Dell's sincerity in his decade-long belief that socialism and Catholicism could be reconciled, and that the two complemented each other, or the genuineness of his religious faith. But once Dell had come to the conclusion that this was in fact a chimera, he did not look back. Like the correspondent to the Clarion quoted above, Dell had been forced to choose between his faith and his politics, and had chosen progressive politics over a mainstream Catholicism that he had concluded was irretrievably reactionary. Dell's letters immediately post-rift indicate a continuing belief in Christianity or at least some form of transcendent spirituality, but a final break with organised religion - Catholic or otherwise. 
Dell was forty when he became disillusioned with his Catholic beliefs. But some of the most dramatic stages of his political and journalistic career were still ahead of him. Indeed, the obituaries published after Dell's death in 1940 barely mention his 'Catholic period', commencing his story with his move to Paris in 1905. On 31 July 1914, Dell was dining at the Café du Croissant in Paris when, a matter of feet away, the French socialist leader Jean Jaurès was shot dead by an assassin. Dell filed a report describing the incident in detail to his paper. ${ }^{72}$ Dell went on to serve as the Manchester Guardian's correspondent in Paris during the First World War. In 1918, having reported on a secret session of the French Chamber on proposals for a separate peace with Austria-Hungary, Dell was expelled on the personal orders of Clemenceau at a few hours' notice. ${ }^{73}$ It would be several years before Dell was allowed back into France, but after sometime as a resident of Berlin, he resumed his post as correspondent for the same paper in Paris in $1929 .{ }^{74}$ In 1920 Dell had published My Second Country (France), in which he returned to many of the themes he had struggled with since the 1890s. In the introduction to this work Dell aptly commented that '[Since the 1870 s] my opinions on almost every subject have changed more than once, as must the opinions of any man that has lived more than fifty years in this world, unless his existence has been that of a vegetable... ${ }^{75}$ My Second Country is unambiguous in its hostility towards organised Catholicism: "The Church is the last hope of the reactionaries... The majority of Catholic men, at any rate, rather accept the dogmas of the Church than believe in them: they swallow them whole, so to speak, and think no more about them for the rest of their lives.' The Modernists, Dell continued, '[were] doomed to failure... All the attempts, however sincere, to adapt the Church to democracy or to reconcile it with science only serve to confuse people's minds and to obscure the incompatibility of Catholicism with both. ${ }^{76}$

Dell, who twenty years previously had prophesised the extinction of 'catastrophic socialism', now declared his support for Russian Bolshevism, the inevitability of revolutionary violence, 
and the Dictatorship of the Proletariat. ${ }^{77}$ A year after this, in Socialism and Personal Liberty, Dell had again revised his opinions on the efficacy of violent revolution. Still hostile to the Catholic Church, and indeed predicting the Vatican concordat with Mussolini ('the Catholic Church would no doubt tolerate a system of State monopoly, if Church property were left intact'), Dell also presciently described the future course of the Soviet regime:

A centralised system of State Socialism will never lead to anything, in my opinion, but more and more State and more and more centralisation. And freedom will never be attained by the suppression of freedom. It may be suppressed at first in the interest of the proletariat: it will end in being suppressed in the interest of the Government. ${ }^{78}$

Dell's final completed monograph was published in 1934. Germany Unmasked, based on Dell's experiences in Berlin immediately after the Nazis took power, stressed the essential irrationality of National Socialism, and the dangerous and insatiable dynamics driving it. 'If Al Capone had been elected President of the United States and had proceeded to govern the country with the aid of the gangsters and the Ku Klux Klan, the result would have been something like the Nazi regime, but more empirical and less logical. ${ }^{79}$ Dell spent his remaining years attempting to alert British and French audiences to the threat posed by Nazi Germany.

\section{Conclusion}

Dell's (early) intellectual journey, from his comfortable Anglican childhood to involvement as a young man in the heady atmosphere of nascent metropolitan socialism and trade union organisation, and then to his adoption of the Catholic faith, and finally a total rejection of organised Catholicism in its Vatican-based form, was a dramatic one. It ended in an irreconcilable break with what been the major influence in Dell's politics and world view 
up to that point. But in many respects Dell's experience was symptomatic of a wider phenomenon taking place in the final decades of the nineteenth century for young men and women of Dell's class and position. In a world where old certainties were rapidly being discarded or obliterated, there was a deep human need to replace the old, rejected modes of living and believing with new totems, new causes to commit to. Dell was an exception in that he adopted not one cause but two, and attempted to fuse the two together. In doing so he brought into question what exactly constituted socialism and what defined Catholicism. Dell's experiences proved the fluidity of the former and the rigidity of the latter in the late nineteenth century. 'Socialism' was infinitely malleable in the 1890 s, with no fixed definition of what constituted the political 'left', no enshrined party 'line' and little of the inner-party discipline that would characterise both the Labour Party and the Communist Party of Great Britain after the First World War. ${ }^{80}$ Memberships were overlapping and porous, and the ideological boundaries ever-shifting. Into the late-Victorian period leading socialists sought to arrive (largely unsuccessfully) at a definition of what they represented, and these attempts sometimes resulted in ideology being ethnically, or, in Dell's case, religiously demarcated. Catholicism, however, with its strict pyramidal leadership structure, the doctrine of papal infallibility, and the ultimate censure of excommunication, had none of this ambiguity. Socialism could be shaped into roughly whatever form the proponent wished it to be; Catholicism could not. Dell, in his attempts to bring socialism and Catholicism together, had also chosen a time when the Catholic leadership, continental and domestic, was in fact becoming if anything more, rather than less, conservative and cautious, as it responded to the efforts of the Modernists as detailed above. The significance of Dell as a thinker in the context of early twentieth century British Catholicism, as compared to Belloc for example, is in his failures, rather than any success, failures that defined the parameters of how far one could go for those who followed him on this obstacle-strewn path. 
Ultimately, instead of Dell's attempts at a confluence, or an outright atheistic rejection of all religious faith, the position successfully adopted by the British social-democratic left on religion in the inter-war period was that articulated by Robert Blatchford in The Clarion in 1901: ‘... Roman Catholicism is a form and system of religious worship, having, essentially, no more connection with a man's political views than have... his views on cricket. ${ }^{81}$ Essentially then, religion for the socialist should be a private matter, not the very public affair that Dell had agonised over in print and at meetings for over a decade. Politics and religion for the moderate socialist should be disconnected, not synthesised.

Whilst the Catholic Modernism of the Edwardian period failed in its objectives, the strain of radical, questioning religious faith that it embodied would exert a significant influence over religion in Britain more generally in the inter-war period. The socially-aware and progressive qualities of the movement documented and argued for by Robert Dell would be adopted by a significant section of the Church of England, and the post-First World War period witnessed a rise in 'Anglican Modernism', which enjoyed a greater degree of success than its Catholic predecessor. An article on the subject from 1922 commented that '... among the older laity, a large number both of men and women, in their private thoughts and in conversations among themselves, practically take up the Modernist point of view, though they may not be able to state their article in precise theological terms. ${ }^{82}$ This set the foundations for an element of Anglicanism sympathetic to the aims of moderate socialism, even, in the case of Hewlett Johnson, the 'Red Dean' of Canterbury, Soviet-style communism.

In the inter-war period, new intellectual currents emerged to tempt the dissatisfied sons and daughters of the middle classes. Both fascism and communism explicitly adopted the imagery and ceremonies of religious faith, appealing to those who had forfeited trust in conventional politics and conventional religion. ${ }^{83}$ Indeed, in the recollections of both former 
fascists and communists, the point at which they embraced the movement is frequently phrased in the language of religious conversion. By the 1930s Dell had completed his political and intellectual journey, and could only warn readers from the side-lines of the dangers posed by the new totalitarian regimes. In the 1960s new forms of the progressive and socially-aware Catholicism that Dell had campaigned for emerged, both those approved by the hierarchy after the Second Vatican council, and, in the case of Liberation Theology, those that still remained outside the pale of 'official' Catholicism. In respect to Liberation Theology, Dell, it is permissible to surmise, would have approved.

\section{Notes}

\footnotetext{
${ }^{1}$ See Stedman Jones, Outcast London, West (ed.), The Victorians and Race, and Brodie, The Politics of the Poor.

2 Johnson, Social Democratic Politics in Britain, 1881-1911, 11.

${ }^{3}$ See Turner, 'The Soul of the Labour Movement', Mayor, The Churches and the Labour Movement, Bevir, The Making of British Socialism, chapter fourteen.

${ }^{4}$ Gilley, 'Catholics and Socialists in Scotland, 1900-30' in Swift and Gilley (eds.) The Irish in Britain.

${ }^{5}$ See special edition of the Heythrop Journal: A Quarterly Review of Philosophy and Theology Vol. X, No.3 (July, 1969), subjecting the beliefs and writing of George Tyrrell to a post-Vatican II analysis. See also Ranchetti, The Catholic Modernists for a trans-European perspective. For discussion of the lives of the principal movers of English Catholic Modernism see Gruber, A Conscience in Conflict, Crews, English Catholic Modernism and Rafferty (ed.), George Tyrrell and Catholic Modernism.

${ }^{6}$ Marx, The Communist Manifesto, 11.

${ }^{7}$ Carlen, The Papal Encyclicals, 1740-1878, 298-299.

${ }^{8}$ Carlen, The Papal Encyclicals, 1878-1903, 11-12.

${ }^{9}$ Belloc, The Church and Socialism, 1-3.

${ }^{10}$ Best, Why No Good Catholic can be a Socialist, 8-9.

${ }^{11}$ Vaughan, A Key to the Social Problem, 16.

12 'Socialists and the Roman Catholic Church' Justice, 22 April 1893.

13 McCelland, Cardinal Manning, 11, 21.

${ }^{14}$ Carlen, The Papal Encyclicals, 1878-1903, 242.

${ }^{15}$ See Misner, Social Catholicism in Europe, 320 for the effect of this encyclical on the European movement for Christian Democracy.
} 
16 'Mr Robert Dell', The Times, 22 July 1940, 'Robert Dell: A Great Journalist', The Manchester Guardian, 22 July 1940.

${ }^{17}$ See Bevir, The Making of British Socialism and Linehan, Modernism and British Socialism for discussion of the fragmented nature of the socialist movement at this point.

${ }^{18}$ London School of Economics Special Collection (hereafter LSE) DELL/7/4 References to Robert Dell in the Peoples' Press, 15 March 1890 - Report of Lambeth meeting.

${ }^{19}$ LSE/DELL/7/4 References to Robert Dell in the Peoples' Press, 29 March 1890 - Report of meeting of railwaymen at Victoria Theatre, Newshaven.

${ }^{20}$ LSE/DELL/7/4 References to Robert Dell in the Peoples' Press, 03 May 1890 - Report of meeting at Morley's Corner, Canning Town.

${ }^{21}$ LSE/DELL/7/4 References to Robert Dell in the Peoples' Press, 03 April 1890 - Report of Shop Assistants' Union, 11 May 1890 - Mass meeting of railwaymen of all grades.

${ }^{22}$ LSE/DELL/7/4 References to Robert Dell in the Peoples' Press, 15 January 1892 - Dell proposes deputation for Cardinal Manning's funeral.

${ }^{23}$ Booth, Life and Labour of the People of London, 168-169.

${ }^{24}$ Bevir, The Making of British Socialism, 34-36, 49.

${ }^{25}$ Aberdeen Free Press, 11 October 1906.

${ }^{26}$ See Morris, News From Nowhere and Blatchford, Merrie England.

${ }^{27}$ See Dansette and Corbett, 'The Rejuvenation of French Catholicism: Marc Sangnier's Sillon' in The Review of Politics, Vol. 15, No.1, (January 1953) pp. 34-52. Breunig, "The Condemnation of the "Sillon": An Episode in the History of Christian-Democracy in France' in Church History, Vol. 26, No.3, (1957), pp.227-244, and Arnal, 'Why the French Christian Democrats were Condemned', Church History, Vol. 49, No.2 (June 1980), pp.188-202.

${ }_{28}$ Dell, The Catholic Church and the Social Question, 23.

${ }^{29}$ Ibid, 39-40.

${ }^{30}$ Ibid.

${ }^{31}$ Ibid, 65.

${ }^{32}$ Benson, A Socialist's view of the Reformation, 4.

${ }^{33}$ Ibid.

${ }^{34}$ Dell, The Catholic Church and the Social Question, 23.

${ }^{35}$ Bevir, The Making of British Socialism, 88-89, 278-279, 285-286.

${ }^{36}$ Stanton, Why We Should Agitate, 11.

${ }^{37}$ Dell, The Catholic Church and the Social Question, 21.

${ }^{38}$ Headlam, The Guild of St. Matthew.

${ }^{39}$ Dell, The Catholic Church and the Social Question, 30.

${ }^{40}$ Ibid, 37-38.

${ }^{41}$ Best, Why No Good Catholic can be a Socialist, 10.

${ }^{42}$ The Clarion, 28 July 1894.

${ }^{43}$ The Clarion, 09 November 1901.

${ }^{44}$ Crews, English Catholic Modernism, 24-25.

${ }^{45}$ See Read, The Dreyfus Affair.

${ }^{46}$ Westminster Diocesan Archives AAW/V/1/1/17 Correspondence of Cardinal Vaughan: Letter to Dr Mivart 09 January 1900.

${ }^{47}$ Sewell, Catholics, 43.

${ }^{48}$ Dell, 'A Liberal Catholic View of the Case of Dr Mivart', The Nineteenth Century, 2, 7.

${ }^{49}$ Ibid, 21.

${ }^{50}$ Crews, English Catholic Modernism, 24.

${ }^{51}$ Sewell, Catholics, 45.

${ }^{52}$ Bourdon, The Church and the Future, 120-121.

${ }^{53}$ Ibid, 162.

${ }^{54}$ Rafferty, 'Tyrrell and the English Jesuits' in Rafferty (ed.), George Tyrrell and Catholic Modernism, 170.

${ }^{55}$ Crews, Catholic Modernism, 46.

${ }^{56}$ Ibid, 54.

${ }^{57}$ Ibid, 67.

${ }^{58}$ Dell, "The Roman Church and Social Democracy", April 1908, 476.

${ }^{59}$ Ibid.

${ }^{60} \mathrm{Ibid}, 473$.

${ }^{61}$ Ibid 476. 
${ }^{62}$ Crews, English Catholic Modernism, 41. Oliver P. Rafferty, 'Tyrrells History and Theology' in Rafferty (ed.), George Tyrrell and Catholic Modernism, 35.

${ }^{63}$ Dell, 'The Papal Attack on France' in The Nineteenth Century (April 1906), 642.

${ }^{64}$ Dell, 'A Liberal Catholic View of the Case of Dr Mivart', The Nineteenth Century, 6.

${ }^{65}$ Robert Dell, 'Church and State in France' in The Saturday Review, 15 October 1906.

${ }^{66}$ Breunig, 'The Condemnation of the "Sillon", Church History, p.233.

${ }^{67}$ Dansette and Corbett, 'The Rejuvenation of French Politics', The Review of Politics, p.48.

${ }^{68} \mathrm{LSE} / \mathrm{DELL} / 7 / 4$ Correspondence Robert Dell to A. Lilley, 14 October 1907.

${ }^{69} \mathrm{LSE} / \mathrm{DELL} / 1 / 1$ Correspondence Robert Dell to family, 25 July 1910.

${ }^{70}$ LSE/DELL/1/1 Correspondence Robert Dell to family, 02 September 1910.

71 'Robert Dell: A Great Journalist', Manchester Guardian, 22 July 1940.

${ }^{72}$ Robert Dell, 'Death of a Socialist', Manchester Guardian, 01 August 1914.

73 'Robert Dell: A Great Journalist', Manchester Guardian, 22 July 1940.

74 'Mr Robert Dell' in The Times, 22 July 1940.

${ }^{75}$ Dell, My Second Country (France), p.vii.

${ }^{76}$ Ibid. 299-302.

${ }_{77}^{7 b i d . ~ 273-274 . ~}$

${ }^{78}$ Dell, Socialism and Personal Liberty, 54-55, 78.

${ }^{79}$ Dell, Germany Unmasked, 21.

${ }^{80}$ Worley, Labour Inside the Gate, 217.

${ }^{81}$ The Clarion, 19 October 1901.

${ }^{82}$ Emmet, 'The Modernist Movement in the Church of England' in The Journal of Religion, Vol. 2, No.6 (November 1922), pp.561-572, p.569.

${ }^{83}$ For a comparable spiritual journey undertaken in the inter-war period, see the career of Douglas Hyde, who went from Methodism to communism and finally converted to Catholicism. Hyde, I Believed. See also Griffin, Fascism, Totalitarianism and Political Religion and Gentile, Politics as Religion.

\section{Bibliography}

Arnal, Oscar L., 'Why the French Christian Democrats were Condemned', Church History, Vol. 49, No.2 (June 1980), pp.188-202

Belloc, Hilaire. The Church and Socialism. London: Catholic Truth Society, 1909.

Benson, T.D. A Socialist's view of the Reformation. Manchester: National Labour Press, 1902.

Best, Kenelm Digby. Why No Good Catholic can be a Socialist . London: Burns and Oates Limited, 1890.

Bevir, Mark, The Making of British Socialism. Princeton, New Jersey: Princeton University Press, 2011

Blatchford, Robert. Merrie England: A Plain Exposition of Socialism . New York: Commonwealth Company, 1895.

Booth, Charles. Life and Labour of the People of London, Third Series: Religious Influences, vol. VI, Outer South London, London,: Macmillan and Co. Ltd., 1902.

Bourdon, Hilaire. The Church and the Future. Edinburgh: Turnbull and Spears, 1903.

Breunig, Charles, 'The Condemnation of the "Sillon": An Episode in the History of Christian-Democracy in France', Church History, Vol. 26, No.3, (1957)., pp.227-244.

Brodie, Marc. The Politics of the Poor: The East End of London, 1885-1914. Oxford: Clarendon Press, 2004

Carlen, Claudia, The Papal Encyclicals, 1740-1878, Wilmington, NA: McGrath Publishing Company, 1981.

Carlen, Claudia, The Papal Encyclicals, 1878-1903, Wilmington, NA: McGrath Publishing Company, 1981 
Crews, Clyde F. English Catholic Modernism: Maude Petre's Way of Faith. Tunbridge Wells:,University of Notre Dame Press, 1984.

Dansette, Adrien and Corbett, James A.,'The Rejuvenation of French Catholicism: Marc Sangnier's Sillon' in The Review of Politics, Vol. 15, No.1, (January 1953), pp.34-52.

Dell, Robert. The Catholic Church and the Social Question. London: Catholic Press Company, 1899.

Dell, Robert. 'A Liberal Catholic View of the Case of Dr Mivart', The Nineteenth Century, vol. 47, no.278 (April 1900)

Dell, Robert. 'The Papal Attack on France' in The Nineteenth Century (April 1906)

Dell, Robert. My Second Country (France. London: John Lane Company, 1920.

Dell, Robert. Socialism and Personal Liberty. London: L. Parsons, 1921.

Dell, Robert. Germany Unmasked. London: M. Hopkinson, 1934.

Emmet, C.W, 'The Modernist Movement in the Church of England' in The Journal of Religion, Vol. 2, No.6 (November 1922), pp.561-572.

Gentile, Emilio. Politics as Religion. Princeton, NJ: Princeton University Press, 2006.

Gilley, Sheridan, 'Catholics and Socialists in Scotland, 1900-30' in Swift, Roger and Gilley, Sheridan (eds.). The Irish in Britain, 1815-1939. London: Pinter Publishers Limited, 1989

Griffin, Roger. Fascism, Totalitarianism and Political Religion. London: Routledge, 2005.

Gruber, Jacob W. A Conscience in Conflict: The Life of St. George Jackson Mivart. New York: Columbia University Press, 1960.

Headlam, Stewart, The Guild of St. Matthew - What it is and who should join it. London: Guild of St. Matthew, 1895, (re-printed 1906).

Heythrop Journal: A Quarterly Review of Philosophy and Theology Vol. X, No.3 (July, 1969)

Hyde, Douglas. I Believed: The Autobiography of a Former British Communist. London: Heinemann, 1951.

Johnson, Graham . Social Democratic Politics in Britain, 1881-1911. New York: The Edwin Mellen Press, 2002

Linehan, Thomas P. Modernism and British Socialism. Basingstoke: Palgrave Macmillan, 2012.

Marx, Karl. The Communist Manifesto. Chicago, 1954.

Mayor, Stephen. The Churches and the Labour Movement. London: Independent Press, 1967

McCelland, Vincent Alan. Cardinal Manning: His Public Life and Influence, 1865-1892. London: Oxford University Press, 1962.

Misner, Paul, Social Catholicism in Europe: From the Onset of Industrialisation to the First World War, London: Darton, Longman and Todd Ltd., 1991.

Morris, William. News From Nowhere: or an Epoch of Rest, Being Some Chapters from a Utopian Romance, London: Reeves and Turner, 1891.

Rafferty, Oliver P. (ed.). George Tyrrell and Catholic Modernism. Dublin: Four Courts Press, 2010. 
Rafferty, Oliver P. 'Tyrrells History and Theology: A Preliminary Survey' in Rafferty, Oliver P. (ed.). George Tyrrell and Catholic Modernism. 21-37 Dublin: Four Courts Press, 2010.

Rafferty, Oliver P. 'Tyrrell and the English Jesuits' in Rafferty, Oliver P. (ed.). George Tyrrell and Catholic Modernism. 131-152 Dublin: Four Courts Press, 2010.

Ranchetti, Michele. The Catholic Modernists: A Study of the Religious Reform Movement, 1864-1907. London Oxford University Press, 1969.

Read, Piers Paul. The Dreyfus Affair: The Story of the Most Infamous Miscarriage of Justice in French History. London: Bloomsbury Publishing, 2012.

Sewell, Dennis. Catholics: Britain's Largest Minority. London: Viking, 2001.

Stanton, C.B. Why We Should Agitate. Aberdare: Haylings and Co., 1903.

Stedman Jones, Gareth. Outcast London: A Study in the Relationship Between the Classes in Victorian Society. London: Penguin Books Ltd.)

Turner, Jacqueline. "The Soul of the Labour Movement: Rediscovering the Labour Church", PhD Thesis, University of Reading, 2010.

Vaughan, Herbert. A Key to the Social Problem: An Appeal to the Laity. London: Burns and Oates, 1893.

West, Shearer, ed. The Victorians and Race. Aldershot, Ashgate Publishing Ltd., 1996

Worley, Matthew. Labour Inside the Gate: A History of the British Labour Party Between the Wars. London: I.B Tauris and Co. Ltd, 2005. 